\title{
RETRACTED: Synthesis and Characterization of Nanocomposite of Functionalized Graphene Oxide with Multi Core-Shell $\mathrm{Fe}_{3} \mathrm{O}_{4}-\mathrm{ZnO}-\mathrm{TiO}_{2}$ Nanoparticles
}

\author{
Ali Nemati',2, Waseem Haider', S. Ghanbarnezhad ${ }^{3}$, Zia Ur Rahman', Syed Nabeel Ahmed \\ ${ }^{1}$ School of Engineering and Technology, Central Michigan University \\ Mt. Pleasant, MI, 48859 \\ nemat1a@cmich.edu \\ ${ }^{2}$ Department of Materials Science \& Engineering, Sharif University of Technology \\ Tehran, Iran \\ nemati@sharif.edu \\ ${ }^{3}$ Department of Materials Engineering, Science \& Research Branch, Islamic Azad University \\ Tehran, Iran
}

Retraction Note - This article has been retracted at the request of the authors since some of the data provided is incorrect. The corresponding author apologizes for the lack of proper preparation prior to submission of the article.

\begin{abstract}
This project involves development and characterization of nanocomposite of functionalized graphene oxide with multi coreshell $\mathrm{Fe}_{3} \mathrm{O}_{4}-\mathrm{ZnO}-\mathrm{TiO}_{2}$ nanoparticles (abbreviated as G-MCSN) with enhanced multi-functional properties. The multi core-shell nanoparticles consist of superparamagnetic core with modified shells of photocatalytic materials. After synthesis of $\mathrm{Fe}_{3} \mathrm{O}_{4}$ nanoparticles (using co-precipitation and solvothermal processes), it was coated with multi shells of $\mathrm{ZnO}$ and $\mathrm{TiO} 2$ (via a facile sol-gel rout). Functionalized graphene oxide was synthesized and mixed with multi core-shell nanoparticles to prepare the nanocomposite. The phases and morphology of the core-shell nanoparticles and the nanocomposite were investigated by X-ray diffraction (XRD), field emission scanning electron microscopy (FE/SEM) and transmission electron microscopy (TEM/SAED). The magnetization hysteresis curves of the samples were conducted by a vibrating sample magnetometer (VSM).

The results showed that the average size of synthesized magnetite nanoparticles were less than $20 \mathrm{~nm}$. The précised control of the procedure resulted in the formation of core-shell structure after coating with $\mathrm{ZnO}$ and $\mathrm{TiO}_{2}$. The median size of core-shell nanoparticles was less than $50 \mathrm{~nm}$. TEM studies revealed the formation of a few layers functionalized graphene oxide (FGO), as well as core-shell nanoparticles. Vibrating sample magnetometer measurement showed that magnetic property of the core-shell nanoparticles was lower than the bare $\mathrm{Fe}_{3} \mathrm{O}_{4}$ nanoparticles (from 40.96 emu. $\mathrm{g}^{-1}$ in bare $\mathrm{Fe}_{3} \mathrm{O}_{4}$ nanoparticles to 20.13 and $12.98 \mathrm{emu}^{-1} \mathrm{~g}^{-1}$ in core-shell nanoparticles). But, when nanocomposite was made (FGO with core-shell nanoparticles), magnetic property was increased in comparison with the coreshell nanoparticles from $12.98 \mathrm{emu} . \mathrm{g}^{-1}$ to $28.18 \mathrm{emu} \cdot \mathrm{g}^{-1}$.
\end{abstract}

Keywords: Functionalized graphene oxide, core-shell nanoparticles, $\mathrm{Fe}_{3} \mathrm{O}_{4} / \mathrm{ZnO} / \mathrm{TiO}_{2}$, TEM, VSM.

\section{Introduction}

Advances in nanotechnology have improved the ability to develop and specifically tailor the microstructural features and properties of functional, structural and biomaterials for high tech applications [1-6]. In recent years, graphene, reduced graphene oxide (RGO) and functionalized graphene oxide (FGO) have been used for different applications. The studies on graphene-based nanocomposites have shown that combining graphene with other materials alters and improves the overall properties of the composite [3-7]. Graphene is known as an electrical conductive material. The interesting aspect of graphene is the correlation between the band structure and its layer structure [8]. The unique feature of graphene creates the ballistic characteristic of electrons in the system. The high speed of electron in graphene (ballistic behaviour of electrons) not only would be beneficial for many applications, but also has the potential to increase the photocatalytic sensitivity of the nanocomposites and have made it suitable materials for many applications. These exceptional electrical and physical properties are suitable for applications in high-speed electronics, data storage devices, flexible touch screens, supercapacitors, 
solar cells, and electrochemical sensors [8-9]. Graphene and graphene oxide have been synthesized in various ways, such as mechanical exfoliation [9], chemical vapor deposition, epitaxial growth, and chemical derivation techniques [9-11]. It has been shown in the literature that when graphene combines with other semiconductor oxides, improve the overall behavior of the system [12-15]. Magnetic nanoparticles (MNPs), such as $\mathrm{Fe}_{3} \mathrm{O}_{4}$, have the ability to overcome numerous challenges and also have strong potential to develop new classes of advanced nanomaterials [16-19]. Different microstructures have been proposed for MNPs, however, one of the main concepts is to design a core-shell nanoparticle structure [20]. However, there are still a lot of unsolved issues in designing and fabricating core-shell nanoparticle structures [19-23]. Studies have shown that $\mathrm{TiO}_{2}$ and $\mathrm{ZnO}$ not only are good photocatalytic materials, but also can be coated on $\mathrm{Fe}_{3} \mathrm{O}_{4}$ very easily [14, 24-31]. There is significant literature available on graphene, $\mathrm{Fe}_{3} \mathrm{O}_{4}, \mathrm{ZnO}$ and $\mathrm{TiO}_{2}$, as well as the combination of graphene with photocatalytic semiconductor and metal oxides, such as $\mathrm{TiO}_{2}, \mathrm{ZnO}, \mathrm{SnO}_{2}, \mathrm{Fe}_{2} \mathrm{O}_{3}, \mathrm{MnO}_{2}$ and $\mathrm{CdS}$ [1,4, 6-11]. Wang et al. synthesized a graphene-based magnetic nanocomposite via in-situ chemical deposition of $\mathrm{Fe}$ (II) and $\mathrm{Fe}$ (III) in alkaline solution for photocatalytic applications [6]. Singh \& co-workers reported a facile soft-chemical approach for the fabrication of $\mathrm{Fe}_{3} \mathrm{O}_{4}$ embedded $\mathrm{ZnO}$ semiconductor nanocomposites [7]. Yusoff et al. [22], Maa et al. [36], J.Y. Park group [37], Zubir et al. [38] and several studies in the field of graphene-based composites were conducted in the past decade [39-44]. Most of the previous researches have been focused on either graphene with one component and/or a single core of magnetic nanomaterials with a single shell [5-8]. Multi components nanocomposites using nanoparticles of multi core-shell structure have not been studied in detail. In this study, development and characterization of nanocomposite of graphene oxide with multi core-shell $\mathrm{Fe}_{3} \mathrm{O}_{4}-\mathrm{ZnO}-\mathrm{TiO}_{2}$ nanoparticles with enhanced multi-functional properties is reported.

\section{Experimental Procedure}

This paper presents synthesis and characterization of a complex ceramic nanocomposite of graphene with multi coreshell nanoparticles. The nanoparticles will have a core-shell structure of magnetite core with photocatalytic semiconductors shells. The proposed ceramic nanocomposite consists of two major elements: (i) functionalized graphene oxide and (ii) multi core-shell nanoparticles. A superparamagnetic $\mathrm{Fe}_{3} \mathrm{O}_{4}$ nanoparticles were synthesized as a core material. The core was subsequently coated with photocatalytic shells of $\mathrm{ZnO}$ and $\mathrm{TiO}_{2}$, respectively. Finally, the multi core-shell nanoparticles were mixed with the functionalized graphene oxide to form the nanocomposite.

Ferric chloride hexahydrate $\left(\mathrm{FeCl}_{3} \cdot 6 \mathrm{H}_{2} \mathrm{O}\right)$, polyvinyl-pyrrolidone (PVP, $\left.\mathrm{K} 30\right)$, urea $\left(\mathrm{CO}\left(\mathrm{NH}_{2}\right)_{2}\right)$ and ethylene glycol (EG), Zinc acetate dehydrate $\left(\mathrm{C}_{4} \mathrm{H}_{6} \mathrm{O}_{4} \mathrm{Zn} .2 \mathrm{H}_{2} \mathrm{O}\right)$, Tetrabutyl titanate, sodium hydroxide $(\mathrm{NaOH})$, ethanol $\left(\mathrm{C}_{2} \mathrm{H}_{6} \mathrm{O}\right)$, graphite, potassium permanganate $\left(\mathrm{KMnO}_{4}\right)$, sulfuric acid $\left(\mathrm{H}_{2} \mathrm{SO}_{4}\right)$, nitric acid $\left(\mathrm{H}_{2} \mathrm{NO}_{3}\right)$, hydrogen peroxide $\left(\mathrm{H}_{2} \mathrm{O}_{2}\right)$, sodium borohydride $\left(\mathrm{NaBH}_{4}\right)$, and other materials were purchased from Sigma Aldrich and Fluka. All materials were of reagent grade and used as received without any further purification. Sequential experimental processing steps were conducted to prepare functionalized graphene oxide, magnetic nanoparticles, core-shell nanoparticles and nanocomposite. Graphene was synthesized by modified Hummer's method using graphite. Afterwards, graphene will be functionalized. Graphene was characterized by FTIR, Raman, XRD (Philiphs, Cu K $\alpha \lambda=1.540 \AA$, 40kV, $25 \mathrm{~mA}$ ), FE/SEM and TEM/SAED. FGO was prepared from graphite via exfoliation technique. Figure 3a shows the schematic presentation of functionalized graphene oxide. Magnetic nanoparticles (MNPs) were synthesized applying co-precipitation method. The general procedure consists of mixing and stirring of $\mathrm{FeCl}_{2} \cdot 4 \mathrm{H}_{2} \mathrm{O}+\mathrm{FeCl}_{3} \cdot 6 \mathrm{H}_{2} \mathrm{O}$ with other chemicals. Subsequently, it was put in autoclave. The nanoparticles were obtained after centrifuging and drying of the solution. After preparation of $\mathrm{Fe}_{3} \mathrm{O}_{4}$ nanoparticles (as a core materials), the $\mathrm{ZnO}$ coating was achieved by mixing zinc acetate dehydrate in diethylene glycol medium in the presence of $\mathrm{Fe}_{3} \mathrm{O}_{4}$ nanoparticles. Then, the coating of $\mathrm{TiO}_{2}$ was carried out by solvothermal method by using titanium tetra isopropoxide solution. Graphene oxide (GO) was prepared from graphite via exfoliation techniques. Finally, $\mathrm{Fe}_{3} \mathrm{O}_{4}-\mathrm{ZnO}^{-\mathrm{TiO}_{2}}$ multi coreshell nanoparticles was combined and synthesized with functionalized graphene oxide.

\section{Results and Discussion}

\subsection{Graphene Synthesis and Characterization}

Infrared (IR), X-ray diffraction (XRD) and Raman spectra of graphite, graphite oxide and graphene sheet are shown in figures $1 \mathrm{a}, 1 \mathrm{~b}$ and $1 \mathrm{c}$, respectively. From the XRD patterns (figure $1 \mathrm{~b}$ ), it is evident that the characteristic peak of graphite $\left(2 \theta=26.5^{\circ}\right)$ corresponding to 002 plane, is almost diminished in graphite oxide and graphene. Instead, new peaks at $10.8^{\circ}$ (graphite oxide) and $23.9^{\circ}$ (graphene) have appeared. The new peak in graphite oxide corresponds to 001 plane and suggests the successful oxidation of graphite to graphene oxide. The shift in XRD peak after sonication of graphite oxide could be attributed to the formation of graphene sheets. The new peak at $23.9^{\circ}$ is associated with 002 plane of $\mathrm{sp}^{2}$ carbon atoms. In 
the Raman spectra (figure 1c), graphite exhibited a G band peak at $1579 \mathrm{~cm}^{-1}$, which could be associated with the stretching vibrations of $\mathrm{sp}^{2}$ bonded in-plane carbon atoms. In the case of graphite oxide and graphene sheets, the $\mathrm{G}$ band vibrations originated at relatively higher wavenumbers of $1597 \mathrm{~cm}^{-1}$ and $1601 \mathrm{~cm}^{-1}$, respectively, compared to graphite. Another band, known as the D band, was observed at $1359 \mathrm{~cm}^{-1}$ (graphite oxide) and $1352 \mathrm{~cm}^{-1}$ (graphene). The occurrence of D band in the Raman spectrum of graphite oxide spectrum also suggested the oxidation of graphite [45]. TEM studies revealed the formation of a few layers functionalized graphene oxide (FGO), as well as core-shell nanoparticles. TEM image spectra of functionalized graphene oxide is shown in figures 1d [45].
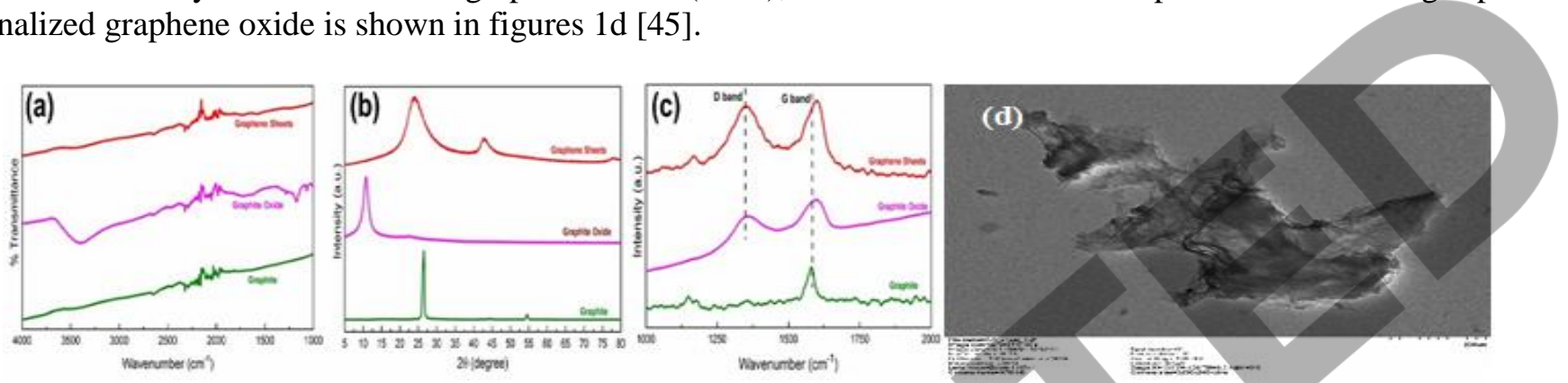

Fig. 1: Characterization of graphite, graphite oxide and graphene by: a) Infrared spectra, b) XRD c) Raman spectra [45] and d)

TEM image of graphene oxide.

\subsection{Nanoparticles and Composite Preparation and Characterization}

FESEM/SEM and TEM images of bare MNPs, MNPs coated with ZnO are shown in figure 2 . As shown in figure 2a, the $\mathrm{Fe}_{3} \mathrm{O}_{4}$ nanoparticles were clusters of fine particles clinging together and the aggregates are spherical in shape with an average size of $20.0 \mathrm{~nm}$. The agglomerated clusters of particles are due to the magneto-static coupling between the particles. Microstructural studies revealed that the control of the procedure resulted in the formation of core-shell structure after coating with $\mathrm{ZnO}$ and $\mathrm{TiO}_{2}$. The median size of $\mathrm{Fe}_{3} \mathrm{O}_{4} / \mathrm{ZnO}$ core-shell nanoparticles was less than $50 \mathrm{~nm}$. Figure $2 \mathrm{~b}$, shows the FESEM image of MNPs coated with $\mathrm{ZnO}$. It is obvious that it is impossible to show the nature of core-shell structure with this type of SEM. Figures 2c and 2d show the TEM image of bare MNPs and ZnO coated MNPs nanoparticles, respectively. This is clearly an indicative of the formation of $\mathrm{ZnO}$ shell on top of MNPs.

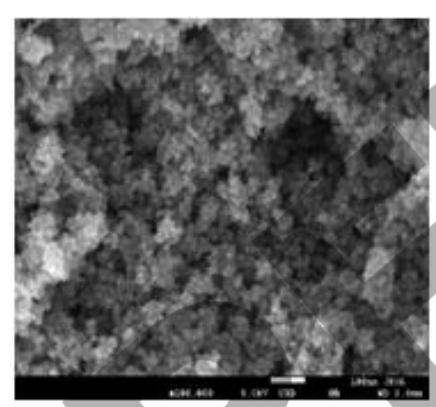

a

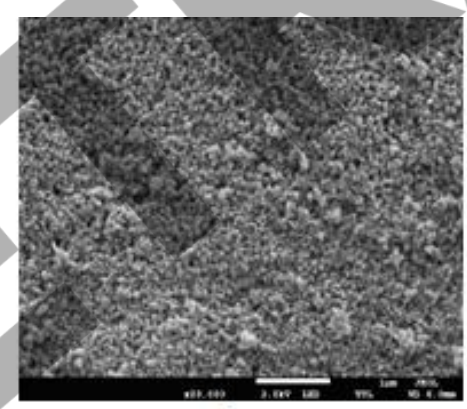

b

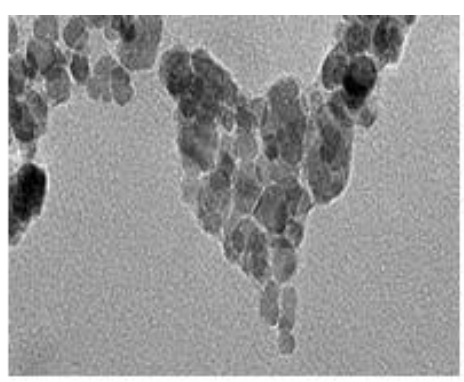

$\mathrm{C}$

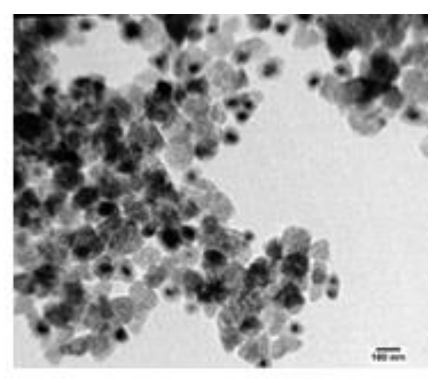

d

Fig. 2: a) FESEM images of bare MNPs, b) FESEM images of ZnO coated MNPs, c)TEM image of bare MNPs and d) TEM image of MNPs coated with $\mathrm{ZnO}$.

TEM images of MNPs coated with $\mathrm{ZnO}$ and $\mathrm{TiO}_{2}$ are shown in figure 3. Figures $3 \mathrm{a}$ and $3 \mathrm{~b}$ show the TEM images of MNPs/ZnO coated with $\mathrm{TiO}_{2}$ at low and high magnification, respectively. Figures $3 \mathrm{c}$ and $3 \mathrm{~d}$ show the TEM image of MNPs/ZnO coated with $\mathrm{TiO}_{2}$ at low and high magnification.

Figure 4 shows the XRD patterns of bare MNPs, MNPs coated with $\mathrm{ZnO}$ and $\mathrm{TiO}_{2}$. As shown in figure 10a, the diffraction peaks of bare $\mathrm{Fe}_{3} \mathrm{O}_{4}$ are clear at different $2 \theta\left(30.10^{\circ}, 35.57^{\circ}, 43.20^{\circ}, 53.68^{\circ}, 57.17^{\circ}, 62.89^{\circ}, 71.3^{\circ}\right.$ and $\left.74.31^{\circ}\right)$, which correspond to miller indices of (220), (311), (400), (422), (511), (440), (020) and (533), respectively. This is in accordance with the $\mathrm{Fe}_{3} \mathrm{O}_{4}$ PDF data (JCPDS file \# 19-0629) and no peak of any other phase/s was detected. The mean crystalline size of $\mathrm{Fe}_{3} \mathrm{O}_{4}$ was evaluated to be between 5-10 nm, from the line broadening of the XRD peaks, using the following equation Scherrer's formula: 


$$
L=\frac{K \lambda}{\beta \operatorname{Cos} \theta}
$$

where: $\mathrm{L}$ is the mean size of the ordered (crystalline) domains, $\mathrm{K}$ is the shape factor typical value of about $0.9, \lambda$ is the $\mathrm{X}$ ray wavelength, $\beta$ is the line broadening at half the maximum intensity (FWHM), $\theta$ is the Bragg angle (in degrees).

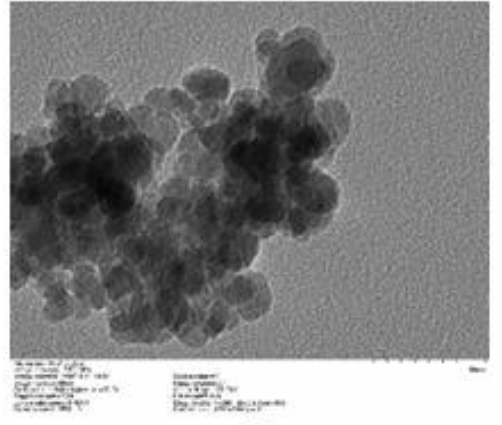

a

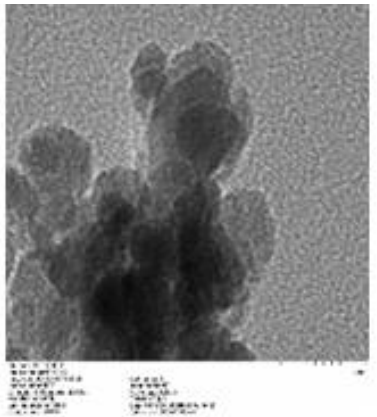

b

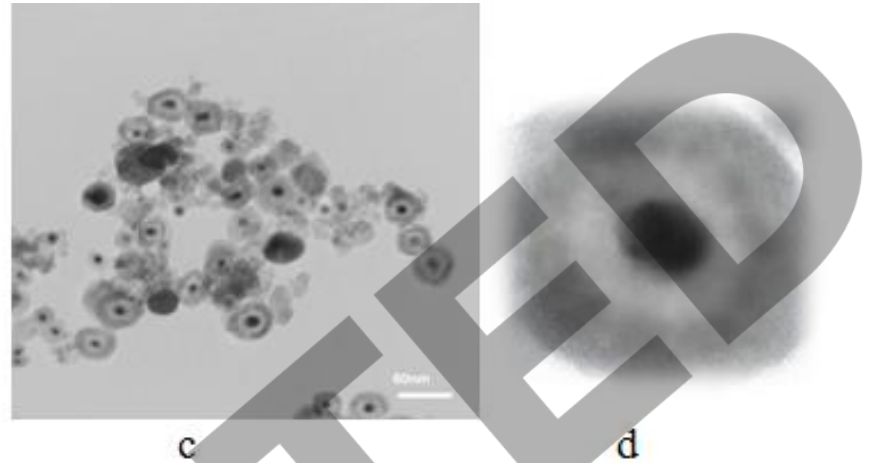

c

Fig. 3: TEM images of MNPs/ZnO/TiO 2 nanoparticles at low and high magnification.

Figure 4 shows $\mathrm{XRD}$ patterns of the $\mathrm{Fe}_{3} \mathrm{O}_{4}$ nanoparticles after coating with $\mathrm{ZnO}$ and $\mathrm{TiO}_{2}$. In this figure, new non-magnetite related peaks at $31.78^{\circ}, 34.43^{\circ}, 36.24^{\circ}, 47.52^{\circ}, 56.56^{\circ}, 62.86^{\circ}, 66.28^{\circ}, 67.90^{\circ}$ and $68.91^{\circ}$ were observed. The position and relative intensity of these new peaks match well with (100), (002), (101), (102), (110), (103), (200), (112) and (201) planes of the standard date for the hexagonal wurtzite structure of the bulk ZnO (JCPDS file No. 36-1451]. No peaks corresponding to any other phase/s are detected, indicating that there has been no reaction between $\mathrm{Fe}_{3} \mathrm{O}_{4}$ and $\mathrm{ZnO}$ during the coating of magnetite core process. The mean crystalline size of $\mathrm{Fe}_{3} \mathrm{O}_{4} @ \mathrm{ZnO}$ was evaluated to be about $25 \mathrm{~nm}$, from the line broadening of the XRD peaks, using the Scherrer's formula. Figure 4 also shows the XRD pattern of $\mathrm{ZnO} / \mathrm{TiO}_{2}$ coated MNPs, which confirms the existence of $\mathrm{ZnO} / \mathrm{TiO}_{2}$ on the surface of the MNPs. This was clearly confimed by detecting the main peaks of $\mathrm{ZnO}$ and $\mathrm{TiO}_{2}$ along with main peaks of $\mathrm{Fe}_{3} \mathrm{O}_{4}$.

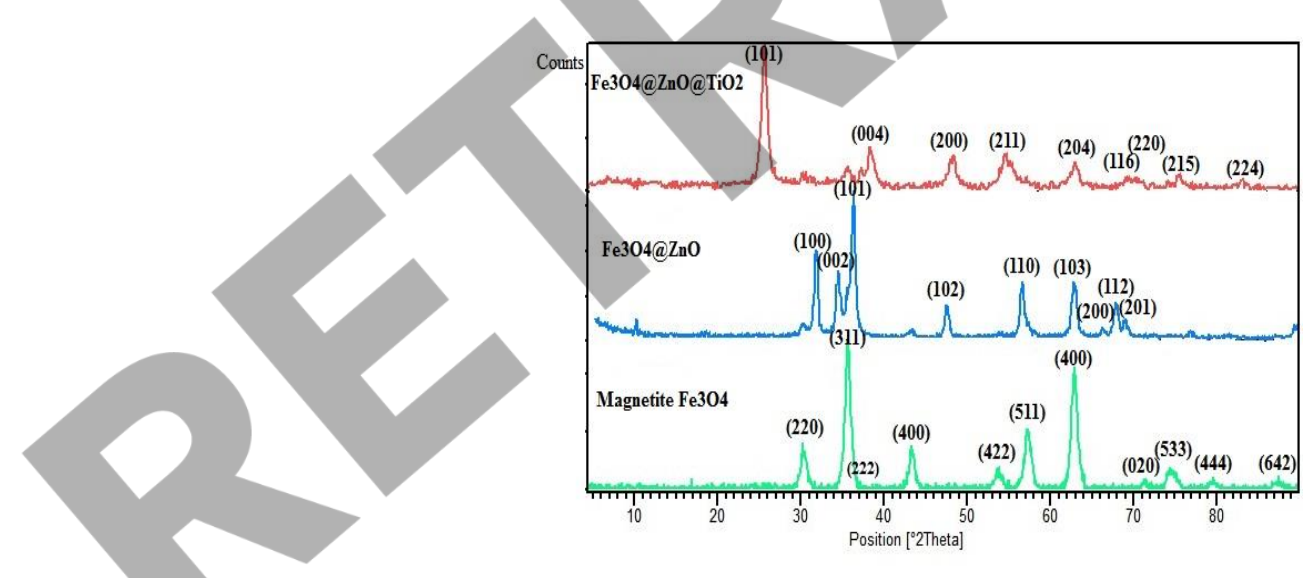

Fig. 4: XRD pattern of bare MNPs, $\mathrm{MNPs} / \mathrm{ZnO}$ and $\mathrm{MNPs} / \mathrm{ZnO} / \mathrm{TiO}_{2}$ nanoparticles.

\subsection{Magnetic Properties Evaluation}

The magnetic properties of the fabricated nanoaprticles as well as nanocomposites were examined at room temperature on a magnetometer and compared $\mathrm{Fe}_{3} \mathrm{O}_{4}$. The magnetic property of MNPs nanoparticles and nanocomposite were measured is shown in figure 5. The magnetization curves in figure 5 showed that the bare $\mathrm{Fe}_{3} \mathrm{O}_{4}$ nanoparticles had high magnetization saturation $\left(\mathrm{M}_{\mathrm{S}}\right)$ value of $40.96 \mathrm{emu}^{\mathrm{g}} \mathrm{g}^{-1}$. As it was anticipated, it is lower than its bulk value (about $90 \mathrm{emu} \cdot \mathrm{g}^{-1}$ ). This decrease can be attributed to the disorder of magnetic moments of surface layer atoms in nanoparticles, as it has been mentioned in the literature [46-48]. The data indicated that magnetic property of the $\mathrm{Fe}_{3} \mathrm{O}_{4} / \mathrm{ZnO}$ core-shell nanoparticles was lower than the bare $\mathrm{Fe}_{3} \mathrm{O}_{4}$ MNPs (from 40.96 emu.g ${ }^{-1}$ in bare $\mathrm{Fe}_{3} \mathrm{O}_{4}$ nanoparticles down to 20.13 emu. ${ }^{-1}$ in $\mathrm{Fe}_{3} \mathrm{O}_{4} / \mathrm{ZnO}$ nanoparticles). As it was expected in $\mathrm{Fe}_{3} \mathrm{O}_{4} / \mathrm{ZnO}-\mathrm{TiO}_{2}$ sample, magnetic property of the nanoparticles was even lower (from $20.13 \mathrm{emu}^{-\mathrm{g}^{-1}}$ 
in $\mathrm{Fe}_{3} \mathrm{O}_{4} / \mathrm{ZnO}$ and to 12.98 emu.g $\mathrm{g}^{-1}$ in $\mathrm{Fe}_{3} \mathrm{O}_{4} / \mathrm{ZnO} / \mathrm{TiO}_{2}$ ). This is because $\mathrm{ZnO}$ and $\mathrm{TiO}_{2}$ nanoparticles does not have suitable magnetic property. That is why; they have diminished the magnetic property of bare $\mathrm{Fe}_{3} \mathrm{O}_{4} \mathrm{MNPs}$, as well. When nanocomposite was made ( $\mathrm{GO}$ with $\mathrm{Fe}_{3} \mathrm{O}_{4} / \mathrm{ZnO} / \mathrm{TiO}_{2}$ nanoparticles), magnetic property of the nanocomposites was increased from 12.98 emu. $\mathrm{g}^{-1}$ to 28.18 emu.g $\mathrm{g}^{-1}$.

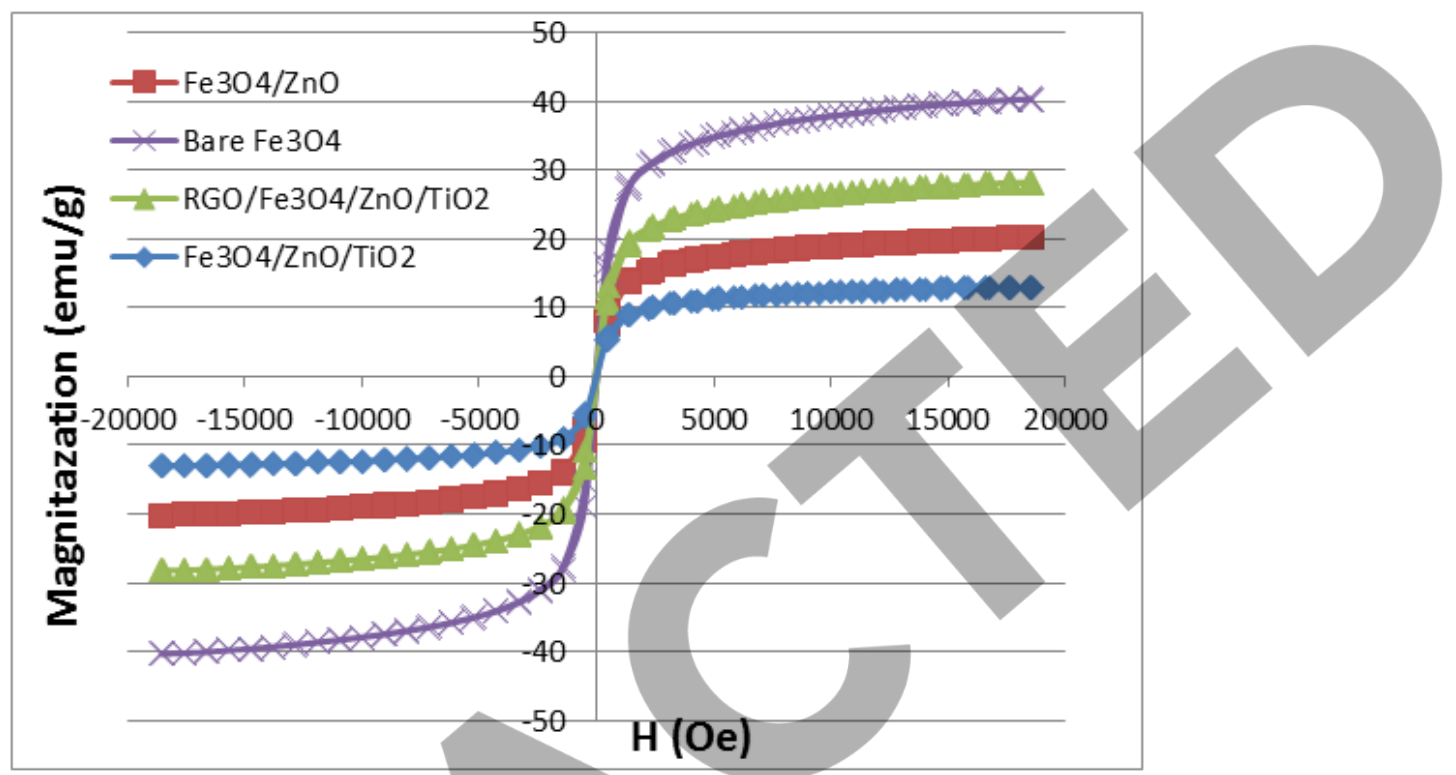

Fig. 5: The magnetic property of different samples.

\section{Conclusions}

In this paper, a nanocomposite of functionalized graphene oxide with multi core-shell $\mathrm{Fe}_{3} \mathrm{O}_{4}-\mathrm{ZnO}-\mathrm{TiO}_{2}$ nanoparticles was synthesized successfully. The results showed that the average size of synthesized magnetite and core-shell nanoparticles were less than $20 \mathrm{~nm}$, and $50 \mathrm{~nm}$, respectively. TEM studies revealed the formation of a few layers functionalized graphene oxide (FGO), as well as core-shell nanoparticles. Vibrating sample magnetometer measurement showed that magnetic property of the bare $\mathrm{Fe}_{3} \mathrm{O}_{4}$, core-shell nanoparticles and nanocomposite were $40.96 \mathrm{emu}^{-\mathrm{g}^{-1}}, 20.13 \mathrm{emu}^{\mathrm{g}} \mathrm{g}^{-1}, 12.98$ and 28.18 emu. $\mathrm{g}^{-1}$, respectively.

\section{References}

[1] M. Bououdina, "Handbook of research on nanoscience, nanotechnology and advanced materials," IGI Global, pp. 164-176, 2014.

[2] S. Zanganeh, G. Hutter, R. Spitler, O. Lenkov, M. Mahmoudi, A. Shaw, P. J. Sakari, H. Nejadnik, S. Goodman, M. Moseley, C. L. Marie, H. Elisabeth, "Iron oxide nanoparticles inhibit tumor growth by inducing pro-inflammatory macrophage polarization in tumor tissues," Nature Nanotechnology, vol. 11, pp. 986-994, 2016.

[3] N. O. Weiss, H. Zhou, L. Liao, Y. Liu, S. Jiang, Y. Huang, and X. Duan, "Graphene: An emerging electronic material," Advanced Materials, vol. 24 no. 43, pp. 5782-5825, 2012.

[4] R. K. Singh, R. Kumar and D. P. Singh "Graphene oxide: strategies for synthesis, reduction and frontier applications," Royal Society of Chemistry, Advance Journal, vol. 6 no.1, pp. 64993-65011, 2016.

[5] M. Mahmoudi, S. Sant, B. Wang, S. Laurent, T. Sen, "Superparamagnetic iron oxide nanoparticles (SPIONs): development, surface modification and applications in chemotherapy," Advanced Drug Delivery Reviews, vol. 63, pp. 24-46, 2011.

[6] T. Wang, Z. Liu, M. Lu, B. Wen, Q. Ouyang, Y. Chen, C. Zhu, P.Gao, C. Li, M. Cao, and L. Qi, "Graphene-Fe ${ }_{3} \mathrm{O}_{4}$ nanohybrids: synthesis and excellent electromagnetic absorption properties," Journal of Applied Physics, vol. 113, no. 1, p ID. 024314, 2013.

[7] S. Singh, K. C. Barick and D. Bahadur, " $\mathrm{Fe}_{3} \mathrm{O}_{4}$ embedded $\mathrm{ZnO}$ nanocomposites for the removal of toxic metal ions, organic dyes and bacterial pathogens," Journal of Materials Chemistry A, vol. 1, pp. 3325-33, 2013. 
[8] E. P. Randvir, D. A. C. Brownson, C. E. Banks, "A decade of graphene research: production, applications and outlook," Materials Today, vol. 17, pp. 426-432, 2014.

[9] R. Muñoz, C. Gómez-Aleixandre, "Review of CVD synthesis of graphene," Chemical Vapor Deposition Journal, vol. 19 no. 1, pp. 297-322, 2013.

[10] W. S. Hummers, R. E. Offeman, "Preparation of graphitic oxide," Journal of American Chemical Society, 1958 , vol. 80 no. 6, pp. 1339-1339.

[11] J. Park, K. An, Y. Hwang, J. G. Park, H. J. Noh, J. Y. Kim, J. H. Park, N. M. Hwang, and T. Hyeon, "Ultra-largescale syntheses of monodisperse nanocrystals," Nature Materials., vol. 3, pp. 891-895, 2004.

[12] M. Bengtsson, N. Castellote, "Heterogeneous photocatalysis on construction materials: effect of catalyst properties on the efficiency for degrading $\mathrm{NO}_{\mathrm{x}}$ and self-cleaning," Materials for Construction, vol. 64 no. 314, p. ID 013, 2014.

[13] M. Ghazanfari, F. Johar, A. Yazdani, Journal of Ultrafine Grained and Nanostructured Materials, vol. 47, pp. 97$103,2014$.

[14] F. Hossinian, A. Nemati, and Y. F. Joya, "Synthesis of C-N-Y tri-doped TiO2 photocatalyst for MO degradation and characterization," Materias Research Express, vol. 2, no. 10, p. ID 105011, 2015.

[15] A. Akyol, H. Yatmaz, M. Bayramoglu, Applied Catalysis B: Environmental, vol. 54, pp. 19-24, 2004.

[16] L. Sophie, M. Mahmoudi, "Superparamagnetic iron oxide nanoparticles: promises for diagnosis and treatment of cancer," International Journal of Molecular Epidemiology and Genetics, vol. 2, no. 4, pp. 367-390, 2011.

[17] V. P. Torchilin, "Drug targeting," European Journal of Pharmaceutical Sciences, vol. 11, pp. 81-91, 2000.

[18] J. Dobson, "Magnetic nanoparticles for drug delivery," Drug Development Research, vol. 67, pp. 55-60, 2006.

[19] V. H. Dinder and H. C. Weinstabl, "Surface modified superparamagnetic iron oxide nanoparticles," Monatshefte für Chemie, Chemical Monthly, vol. 138, pp. 315-320, 2007.

[20] R. G. Chaudhuri, S. Paria, "Core/Shell Nanoparticles: Classes, Properties, Synthesis Mechanisms, Characterization, and Applications," Chem. Rev., vol. 112, pp. 2373-2433, 2012.

[21] R. G. Chaudhuri and S. Paria "Core-shell nanoparticles: classes, properties, synthesis mechanisms, characterization, and applications," Chemistry Review, vol. 112, pp. 2373-2433, 2012.

[22] N. Yusoff, S. V. Kumar, A. Pandikumar, N. M. Huang, A. R. Marlinda, and M. N. An'amt, "Core-shell Fe $\mathrm{O}_{4}-\mathrm{ZnO}$ nanoparticles decorated on reduced graphene oxide for enhanced photo electrochemical water splitting," Ceramics International, vol. 41, no.3, pp. 5117-5128, 2015.

[23] S. Singh, K. Barick, D. Bahadur, Journal of Materials Chemistry A, vol. 1, pp. 3325-3333, 2013.

[24] N. Yusoff, S. V. Kumar, A. Pandikumar, N. Huang, A. Marlinda, M. An’amt, Ceramics International, vol. 41, pp. 5117-5128, 2015

[25] F. T. Johra, W.-G. Jung, Applied Catalysis A: General, vol. 491, 52-57, 2015.

[26] N. Ahmadi, A. Nemati, M. Solati-Hashjin, "Synthesis and characterization of co-doped $\mathrm{TiO}_{2}$ thin films on glassceramic," Materials Science in Semiconductor Processing, vol. 26, no. 1, pp. 41-48, 2014.

[27] K. M. Deen, A. Farooq, M. A. Raza, and W. Haider, "Effect of electrolyte composition on $\mathrm{TiO}_{2}$ nano tubular structure formation and its electrochemical evaluation," Electrochimica Acta, vol. 117, pp. 329-335, 2014.

[28] N. Elamin, A. Elsanousi, "Synthesis of ZnO nanostructures and their photocatalytic activity," Journal of Applied and Industrial Sciences, vol. 1, no.1, pp. 32-35, 2013.

[29] J. N. Muhd, and S. Bagheri "Recent developments on titania nanoparticle as photocatalytic cancer cells treatment," Journal of Photochemistry and Photobiology B, Biology, vol. 163, pp. 421-430, 2016.

[30] A. Kołodziejczak-Radzimska, and T. Jesionowski, "Zinc oxide-from synthesis to applications: A Review," Materials Journal, vol. 7, no. 1, pp. 2833-2881, 2014.

[31] Sh. Ge, M. Agbakpe, W. Zhang, L. Kuang, Z. Wu, and X. Wang, "Recovering Fe3O4-ZnO nanocomposites from algal biomass based on hydrophobicity shift under irraiation," ACS applied Materials and interfaces, vol. 7, no. 21, pp. 11677-11682, 2015.

[32] C. Wang, C. Feng, Y. Gao, X. Ma, Q. Wu, Z. Wang, Chemical Engineering Journal, vol. 173, pp. 92-97, 2011.

[33] V. Chandra, J. Park, Y. Chun, J.W. Lee, I.-C. Hwang, K.S. Kim, ACS nano, vol. 4, 3979-3986, 2010.

[34] Z. Geng, Y. Lin, X. Yu, Q. Shen, L. Ma, Z. Li, N. Pan, X. Wang, Journal of Materials Chemistry, vol. 22, 3527-3535, 2012.

[35] Y. Lin, Z. Geng, H. Cai, L. Ma, J. Chen, J. Zeng, N. Pan, X. Wang, European Journal of Inorganic Chemistry, pp. 4439-4444, 2012. 
[36] X. Maa, A. Gonga, B. Chenb, J. Zhengb, T. Chena, Z. Shena, and A. Wua, "Exploring a new SPION-based MRI contrast agent with excellent water-dispersibility, high specificity to cancer cells and strong MRI imaging efficacy," Colloids and Surfaces B: Biointerfaces, vol. 126, pp. 44-49, 2015.

[37] J. Y. Park, S.W. Choi, J. W. Lee, C. Lee, and S. S. Kim, "Synthesis and gas sensing properties of $\mathrm{TiO}_{2}-\mathrm{ZnO}$ coreshell nanofibers core-shell nanofibers," Journal of American Ceramic Soc., vol. 92, no. 11, pp. 2551-2554, 2009.

[38] N. A. Zubir, C. Yacou, J. Motuzas, X. Zhang, J. C. D. da Costa, Scientific reports, vol. 4, p. 4594, 2014.

[39] S. M. Lee, J. H. Kim, J. H. Ahn, "Graphene as a flexible electronic material: mechanical limitations by defect formation and efforts to overcome,", vol. 18, no. 6, pp. 336-344, 2015.

[40] R. Jaiswal, S. Singh, and H. Pande, "Magnetic nanoparticles activated carbon: preparation, characterization and application," Asian Journal Research Chemistry, vol. 8 no. 12, pp. 757-768, 2015.

[41] C. Worsch, M. Buttner, P. Schaaf, R. Harizanova, C. Russel, F. Schmid, and P. Seidel, "Magnetic properties of multicore magnetite nanoparticles prepared by glass crystallization," Journal of Materials Science, vol. 48, pp. 2299$2307,2013$.

[42] X. Yang, X. Zhang, Y. Ma, Y. Huang, Y. Wang, and Y. Chen, "Superparamagnetic graphene oxide- $\mathrm{Fe}_{3} \mathrm{O}_{4}$ nanoparticles hybrid for controlled targeted drug carriers," Journal of Materials Chemistry, vol. 19, pp. 2710-2714, 2009.

[43] M. G. Kochameshki, A. Marjani, M. Mahmoudian, K. Farhadi, "Grafting of diallyldimethyl ammonium chloride on graphene oxide by RAFT polymerization for modification of nanocomposite poly sulfone membranes using in water treatment," Chemical Engineering Journal, vol. 309, pp. 206-221, 2017.

[44] Y. Lu, Y. Yin, B. T. Mayers, Y. Xia, "Modifying the Surface Properties of Superparamagnetic Iron Oxide Nanoparticles through a Sol-Gel Approach," Nano Lett., vol. 2, pp. 183=186, 2002.

[45] Unpublished work, Waseem Haider research group, Central Michigan University, Mt. Pleasant, MI, USA

[46] Z. Q. Li, H. L.Wang, Y. Zi L, J. J. Zhang, Y. S. Zhang, Ceramics International, vol. 41, pp. 10634-10643, 2015.

[47] C. R. Lin, Y. M. Chu, S. C. Wang, Materials Letters, vol. 60, pp. 447-450, 2006.

[48] A. Hasanpour, M. Niyaifar, M. Asan, J. Amighian, Journal of Magnetism and Magnetic Materials, vol. 334, pp. 4144, 2013.

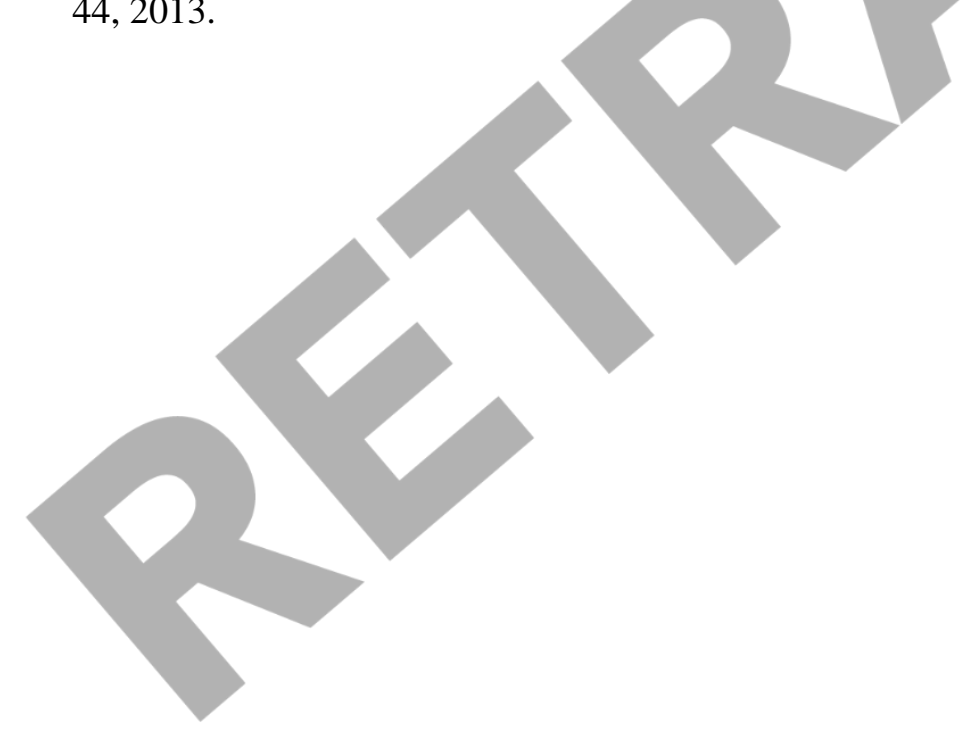

